\title{
Preparation and Evaluation of Electrodes for Solid Polymer Fuel Cells
}

\author{
Steffen MøLLER-HOLST
}

Received December 25, 1995 ; Accepted February 6, 1996

\begin{abstract}
Thin film electrodes for solid polymer fuel cells $\left(0.06-0.1 \mathrm{mg} \mathrm{Pt} / \mathrm{cm}^{2}\right)$ were prepared by spraying electrode material directly onto the Nafion 117 membrane. Variations in cell potential obtained by changing the electrode composition and preparation conditions were investigated. The results showed that both increased polymer content and higher Pt-loading had positive effect on cell performance, whereas increased drying temperature caused a decline in cell performance. Commercial electrodes were modified by vacuum-deposition of a thin layer of $\mathrm{Pt} / \mathrm{Rh}$ alloy on top of the electrode followed by Nafion impregnation. This treatment also gave improved cell performance. Comparison showed that Ptutilization was better for the thin film electrodes than for the modified commercial electrodes, due to a more optimal composition of the electroactive layer. A test station for studying single cell performance was described. The test station provided cell tests over a wide range of operating conditions. Cell performance was tested automatically through computer control.
\end{abstract}

\section{INTRODUCTION}

Fuel cells are promising and efficient devices for direct conversion of chemical energy to electricity. This new technology is expected to play an important role in future energy supply systems. Solid polymer fuel cells (SPFCs) were successfully applied in the Gemini space mission. SPFC performance has significantly improved during the last years and high power densities are now attainable $\left(>1 \mathrm{~W} / \mathrm{cm}^{2}\right)^{1-3)}$. These low temperature fuel cells are attractive and well suited for transportation applications where heat recovery is of minor importance.

A major challenge for improvement of most fuel cell systems has been, and still is, the reduction of cathodic activation overpotentials ${ }^{4,5)}$. The high platinum catalyst loading required to obtain reasonable cathode performance, is a major impediment to the commercialization of the SPFC technology. The polymer fuel cell research effort therefore concentrates on reducing catalyst loading ${ }^{2,6}$, seeking new catalyst materials ${ }^{7}$ and optimizing electrode morphology to improve catalyst utilization $^{8,9)}$. Recent investigations show that $\mathrm{Pt}$ utilization may be enhanced largely by localizing the catalyst close to the electrode membrane interface. Dense thin electrocatalytic films consisting of carbon

Department of Physical Chemistry, Norwegian Institute of Technology, University of Trondheim, (N-7034 Trondheim, Norway)

Key Words: Fuel Cell, Polymer, Electrodes, Platinum, Energy Conversion supported Pt and using polymer conductor as binder, show promising properties ${ }^{2)}$.

When developing new fuel cell electrodes and electrolytes, the materials are tested by applying different electrochemical techniques. The materials are usually studied in contact with acidic aqueous solutions ${ }^{10-13)}$. Difficulties are, however, encountered when trying to obtain good contact between polymer electrolytes and electrodes. Whereas catalyst utilization was almost $100 \%$ in aqueous phosphoric acid $^{14)}$, the corresponding value using polymer electrolytes was considerably lower $(10-20 \%)^{15}$. Under SPFC operation, water is usually supplied as vapor. Membrane properties differ significantly whether the water is supplied as liquid or as vapor $^{16,17)}$. Furthermore, properties of the materials may change during membrane and electrolyte (M\&E) assembling (i.e. hot pressing) ${ }^{18,19}$. The assembling procedure must therefore reflect the chemical stability of the materials in use. This stresses the need of thorough and detailed testing of the cells after the M\&E assembling and under real fuel cell operating conditions.

The aim of the present study is to describe the preparation of thin film electrodes and to study how cell performance is affected by changes in composition, Pt-loading and drying temperature. The electrodes are evaluated in a test station equipped for studies of SPFCs under realistic operating conditions. Single cells containing thin film electrodes have been tested and the results are compared to those of commercial electrodes. 


\section{TEST STATION DESCRIPTION}

A test station for studying single SPFC at low temperatures $\left(<150^{\circ} \mathrm{C}\right)$ was designed. The test station had provisions for temperature, gas pressure and gas flow control. The humidity of the reactant gases was controlled through the temperature of the gas humidifiers. A single cell fixture was designed for rapid dismantling and reassembling. A personal computer was connected to the test station, taking care of data acquisition. Computer routines were made for easy data analysis by use of a worksheet. The different parts of the system are described in detail below.

\subsection{Gas supply and humidification system}

The gas flow system is shown schematically in Fig. 1. Gases were supplied from pressure vessels (20 $\mathrm{MPa}$ ) equipped with pressure reduction valves. The flow of gases were controlled by Brooks Digital Mass Flow Controllers (Model 5850S) and monitored using flowmetres (Brooks, Sho-Rate 1355). Gas pressures were measured by means of manometers (Bourdon) before entering the gas humidifiers. Dry gases were lead through copper tubes to the humidifiers and humidified gases through 316 SS tubes, both of $1 / 4$ " outer diameter. In the gas humidifiers the inlet gases were simultaneously heated and saturated with water. The gas humidifiers were made from $316 \mathrm{SS}$, each heated by means of an electric heating tape (Fibrox ${ }^{\mathrm{TM}}$, Thermolyne Corp.) and cooled by a water coil. The humidity of anode and cathode gases were varied individually by changing the temperatures of the humidifiers. The gases leaving the humidifiers were saturated with water vapor and were lead through isolated tubes to the fuel cell. The humidifiers were operated at a higher temperature than the fuel cell, as recommended in literature ${ }^{20)}$ so the gases leaving the cell were oversaturated. Water leaving the fuel cell was removed from the gases by water separators, before the gases were released to the atmosphere

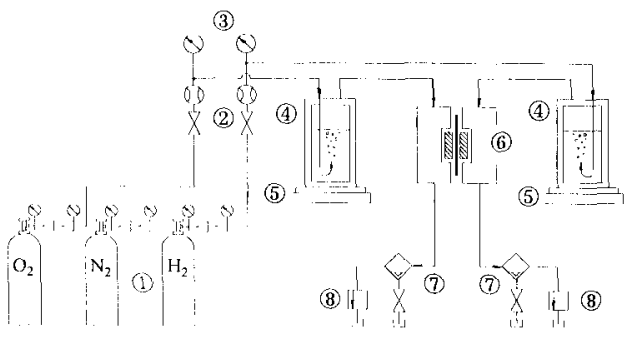

Fig.1 Schematic presentation of the gas flow system. (1) Pressure vessels, (2) Flow controllers and flowmeters, (3) Manometers, (4) Gas humidifiers, (5) Magnetic stirrers, (6) Single cell fixture, (7) Water separators, (8) Pressure controllers. through Brooks Compact Pressure Controllers (Model 5866).

\subsection{Single cell fixture}

A single fuel cell fixture was designed as shown in Fig.2. The outer cylinder of the cell fixture was made from Polyethersulfon (Victrex ${ }^{\mathrm{TM}}$ ). Polyethersulfon (PES) is an amorphous plastic material with adequate properties like high electrical resistance, transparency, low water absorbance, relatively high tensile strength, thermal stability to $200{ }^{\circ} \mathrm{C}$, high chemical resistivity and offers easy workability. Inside each PES cylinder a piston could move in the axial direction, to fit fuel cells with electrodes of different thicknesses. Two guided screws prevented the pistons from rotation. The pistons were made from $316 \mathrm{SS}$ and served also as current collectors. The cell temperature was kept constant by means of two heating elements controlled by a Eurotherm PID-controller and a K-type thermocouple. Cell design was not optimized with respect to gas flow and, thus, the fuel cells were tested at low gas utilization (customarily below $5 \%$ ). The geometric area of the electrode was $3.9 \mathrm{~cm}^{2}$.

\subsection{Instrumentation and data acquisition}

Test station operation data (e.g. temperature, pressure and cell potential) were recorded by a PC using software from National Instruments (NI). The $\mathrm{PC}$ was also used to control some parameters like the pressure, the gas flow etc.

Temperatures and voltages were measured by a HP3457A Multimeter holding a 44492A multiplexer, and the cell current was measured by a Solartron

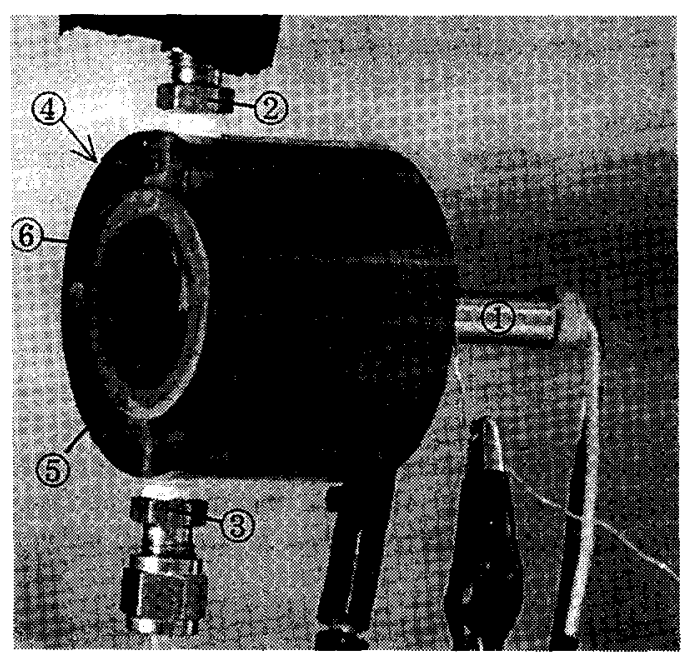

Fig.2 Photograph of one half of the single cell

fixture. Key: (1) Heating element, (2) Gas inlet, (3) Gas outlet, (4) PES cell fixture; (5) Gasket, (6) Membrane and electrode assembly. 
7150 plus Digital Multimeter. These instruments were connected to a PC386 using GPIB interface. The PC also contained a digital $1 / O$ board (NI DAQ PC-DIO24) which controlled the cell load, the gas flows and pressures of the system. The PC-DIO-24-board was connected to a resistance switch box. By means of a relay board (NI DAQ SC-2062) the cell load could be varied from 0.6 to $127 \mathrm{ohm}$ in steps of $1.0 \pm 0.2 \mathrm{ohm}$. Set points to the mass flow controllers were given digitally from the PC-DIO-24-board, whereas the analogue voltage set points of the pressure controllers were obtained by $\mathrm{D} / \mathrm{A}$ converting the digital signals.

The data acquisition program LabView (for Windows ver. 3:01, National Instruments) was used to control these instruments under fuel cell testing. Some instrument drivers were available, whereas others had to be written or modified. Cell data were monitored on screen and saved to file at chosen time intervals in a Microsoft Excel worksheet format for later analysis and calculations.

\subsection{Operation limitations, discussion}

The test station was designed to stand pressures of up to 10 bar ( $1 \mathrm{MPa}$ ), which is twice the usual operation pressure of SPFC. Pressure differences between electrodes are of interest in order to control the water balance in SPFC. A higher cathode pressure (in the range of 1-2 bar (100-200 kPa)) is customarily used in SPFC operation because it increases water diffusion towards the anode and thus counteracts the water transport by electro-osmotic drag. A large gasket area towards the membrane (Fig.2) made it possible to operate with pressure differences between electrodes. Tests with Nafion 117 membranes and Prototech electrodes showed that the cell can operate at pressure differences of at least 3 bar $(300 \mathrm{kPa})$.

The cell temperature may be varied from room temperature to $150^{\circ} \mathrm{C}$. Humidifiers can operate from room temperature to $130{ }^{\circ} \mathrm{C}$. The manual resistance switch box for varying the cell load was not an optimal way of obtaining polarization curves. The switch box is now replaced by an EG\&G PARC Versastat 253 to control the cell current.

Data acquisition by use of the LabView software (NI) has shown to be very useful for handling the fuel cell data acquisition task. One drawback is, however, that ordinary Windows instrument drivers are not applicable in the LabView program.

\subsection{Membrane preparation}

\section{EXPERIMENTAL}

DuPont Nafion 117 membranes were supplied by ElCell AB, Sweden. The membranes were heated to the boiling point in distilled water, transferred to hot 5 $\% \mathrm{H}_{2} \mathrm{O}_{2}\left(85-100{ }^{\circ} \mathrm{C}\right)$ and kept there for 30 minutes to oxidize organic impurities. After 15 minutes in distilled water $\left(\mathrm{T}>70{ }^{\circ} \mathrm{C}\right)$, they were immersed in hot dilute sulfuric acid $\left(0.05 \mathrm{M} \mathrm{H}_{2} \mathrm{SO}_{4}\right)$ at $90{ }^{\circ} \mathrm{C}$ for 30 minutes to remove metallic impurities. The membranes were rinsed several times in distilled water at $\mathrm{T}>70^{\circ} \mathrm{C}$ to remove traces of acid and stored in distilled water until use.

\subsection{Modification of commercial electrodes}

Commercial Prototech electrodes $\left(0.5 \mathrm{mg} \mathrm{Pt} / \mathrm{cm}^{2}\right.$ on Vulcan $\mathrm{XC72}$ ) were supplied by The Electrosynthesis Co., NY, USA. The electrodes were modified by vacuum deposition and impregnation to enhance performance.

A thin layer of $\mathrm{Pt} / \mathrm{Rh}(80 / 20 \%)$ was deposited on top of the electrode under high vacuum $\left(10^{-5}\right.$ torr) using a Coating Unit (Edwards High Vacuum, LTD, Sussex). The amount of $\mathrm{Pt} / \mathrm{Rh}$ was estimated to $30 \pm 5$ $\mu \mathrm{g} / \mathrm{cm}^{2}$ corresponding to a thickness of approximately $15 \mathrm{~nm}$ (non-porous metal).

Then the electrode was impregnated with Nafion 117 solution (5\% mixture in lower aliphatic alcohols and water, Fluka Chemica). The Nafion loading was determined gravimetrically to $1.0 \pm 0.1 \mathrm{mg} / \mathrm{cm}^{2}$ (dry weight) close to the optimal loading recommended by Poltarzewski et al. ${ }^{8)}$.

\subsection{Preparation of thin film electrodes}

3.3.1 Experimental design A screening experiment was designed to study how electrode composition, drying temperature and Pt-loading affected the polarization curve of the single cell. A statistical approach applying factorial design was used in this screening experiment. The design requires few runs per factor studied, indicates major trends, determines direction for further experimentation and provides easy result evaluation. This design was not capable of fully exploring a wide region in the factor space. The purpose of the screening experiment was, however, to indicate the trends. The three factors were given two different levels and thus this was a complete $2^{3}$. factorial design (Fig.4). The levels of the factors are given in Table 1. The effects of the factors were evaluated using the Yates algorithm. For more information on factorial design, see Box et al. ${ }^{21)}$.

3.3.2 Spray deposition Electrode catalyst material (20 wt $\%$ Pt on Vulcan XC72, provided by Johnson Matthey Plc, UK), was mixed with Nafion 117 solution ( $5 \%$ ) and glycerol guided by the procedure given by Wilson and Gottesfeld ${ }^{2)}$. Two suspensions with different polymer (i.e., Nafion) contents were prepared. To facilitate the change in polymer content, while keeping the Pt-loading constant, small amounts of uncatalyzed Vulcan XC72 carbon (Cabot, Netherlands) was added to one of the suspensions. The variation in Pt-loading was obtained by changing 


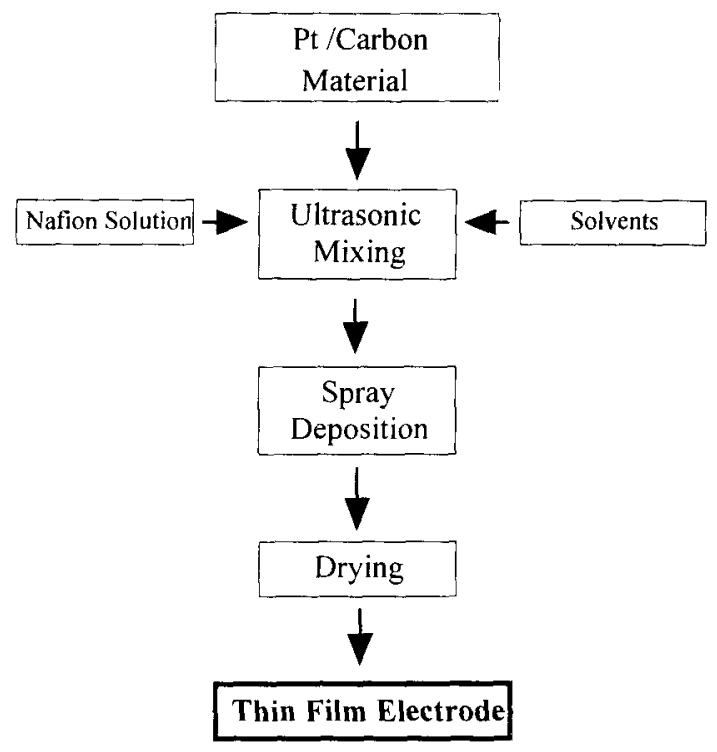

Fig.3 Preparation procedure for the Thin Film Electrodes.

the thickness of the thin electrode layer. The suspension was subject to extensive ultrasound and mechanical mixing before applying it to the Nafion 117 membrane (Fig.3). A thin catalytic active layer was deposited directly onto the membrane by spray deposition using a Badger Airbrush pistol (model 200). The pistol was operated at an air pressure of around 2 bar $(200 \mathrm{kPa})$. Spraying time was typically between 2 and 5 seconds. The spray time was set accurately using an electronically controlled solenoid to operate the pistol trigger. Pt-loading was determined gravimetrically from the amount of suspension supplied to the membrane. The membrane and electrode (M\&E) assembly was dried in a forced convection oven for 30 minutes and stored in cold distilled water for later performance testing.

3.3.3 Limitations of the spray deposition technique The spray deposition technique is limited to thin electrodes when using glycerol as solvent and drying in a forced convection oven at $125-135^{\circ} \mathrm{C}$. Glycerol, like other alcohols, penetrates the membrane and makes it expand ${ }^{18)}$. Thin layers of $\mathrm{Pt} / \mathrm{C}$ are successfully applied to the membrane because drying is faster than the alcohol penetration. At high loadings the membrane expansion was substantial, giving electrodes of non-uniform thickness. Thicker electrode layers may be obtained by applying multiple electrocatalytic layers with intermediate drying. Due to thermal degradation of the proton conductor, the overall drying time should be minimized. Substitution of the glycerol by another solvent, either a more volatile or a less membranepenetrating one, would make thicker uniform electrodes obtainable in one single layer.

\subsection{Cell assembling}

A thermostated sample holder for pressing the electrodes to the membrane was constructed. The holder contained an insulated electric heating tape (Fibrox ${ }^{\mathrm{TM}}$, Thermolyne Corp.) and a K-element thermo-couple connected to a Eurotherm PIDcontroller. The pressure was provided by a Beckman press (Scotland). Prototech electrodes (as-received and modified, chapter 3.2) were pressed onto wet Nafion 117 membranes at 90 bar and $135^{\circ} \mathrm{C}$ for 90 seconds.

In the case of thin film electrodes (chapter 3.3), hot pressing was not applied. An uncatalyzed Prototech carbon cloth (Vulcan XC72) was merely inserted on both electrodes as the M\&E assembly was placed in the single cell fixture.

\subsection{Cell test procedure}

The prepared M\&E assemblies were boiled in $0.05 \mathrm{M} \mathrm{H}_{2} \mathrm{SO}_{4}$ for 30 minutes and rinsed in hot distilled water before they were mounted in the single cell test fixture (Fig.2). Safety precautions were taken by flushing the system with $\mathrm{N}_{2}$ gas for 5-10 minutes before and after every experiment. Cell performance tests were made using pure $\mathrm{H}_{2}$ and $\mathrm{O}_{2}$ gases saturated with water at $85^{\circ} \mathrm{C}$, corresponding to a water vapour pressure of 0.58 bar $(58 \mathrm{kPa})$. The total pressure was $4.5 \mathrm{bar}(450 \mathrm{kPa})$ at both electrodes and the cell temperature was $70{ }^{\circ} \mathrm{C}$.

\section{RESULTS AND DISCUSSION \\ 4.1 Thin film electrodes}

Eight single cells containing electrodes of different treatments were assembled and tested. The cells were compared by their cell potential at a current density of $100 \mathrm{~mA} / \mathrm{cm}^{2}$. In Fig.4 the cell potentials are shown at the comers of the cube. The variation in cell potential was substantial, ranging from 225 to 675 $\mathrm{mV}$. The main effects of the factors are given in Table 1.

Table 1 Levels and main effects on cell potential, $E$, of the factors in the $2^{3}$-experiment.

\begin{tabular}{|l|c|c|c|}
\cline { 2 - 4 } \multicolumn{1}{c|}{} & \multicolumn{2}{c|}{ Levels } & Effect on $E^{*}$ \\
\hline Factor & Low & High & $(\mathrm{mV})$ \\
\hline Nafion $(\%$ by weight) & 15 & 25 & +123 \\
\hline Drying Temp. $\left({ }^{\circ} \mathrm{C}\right)$ & 125 & 135 & -87 \\
\hline Pt-loading $\left(\mathrm{mg} / \mathrm{cm}^{2}\right)$ & 0.06 & 0.1 & +225 \\
\hline
\end{tabular}




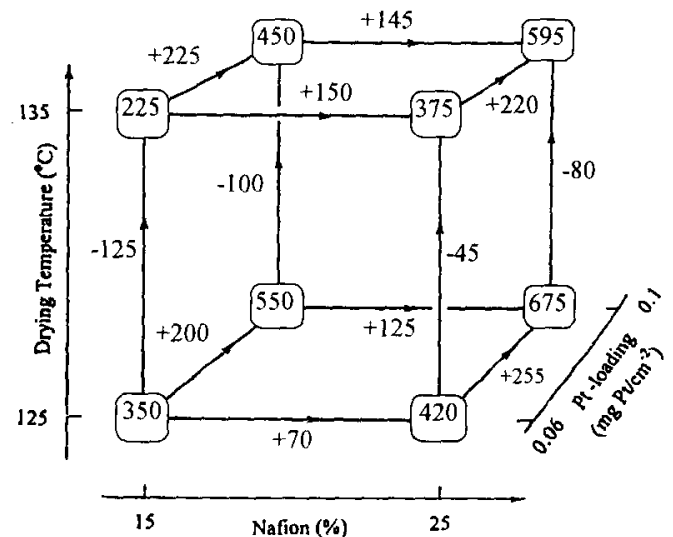

Fig.4 A geometrical representation of the experimental factorial design (chapter 3.3.1). Cell potential $(\mathrm{mV})$ at a current density of $100 \mathrm{~mA} / \mathrm{cm}^{2}$ is given at the corners of the cube.

Both hydrophilic and hydrophobic regions are needed in the electrode to facilitate the water and gas transport, respectively. The results (Table 1) show that the increase in Nafion content from 15 to $25 \mathrm{wt} \%$ gave (in average) a gain in cell potential of $123 \mathrm{mV}$ at $100 \mathrm{~mA} / \mathrm{cm}^{2}$. Thus, the gas transport may be a bottle neck at low Nafion contents. More important is, however, the improved performance connected to the increased proton conductivity in the electrode layer of higher Nafion content. The electron conducting carbon and the proton conducting polymer must both be able to establish a three dimensional network within the electrocatalytic layer. One possible explanation of the low cell potential at low Nafion contents, is that the amount of polymer is too low to facilitate the creation of this network in the polymer phase.

The lower cell potentials at high drying temperature indicated that the polymer material experiences some chemical degradation during the 30 minutes of drying at $135^{\circ} \mathrm{C}$. This degradation may be reduced by using the polymer in the $\mathrm{Na}^{+}$or $\mathrm{Li}^{+}$-form during drying followed by re-protonation ${ }^{18}$.

The increase in Pt-loading had the most pronounced effect on cell potential. Cell potentials were generally low for the $0.06 \mathrm{mg} \mathrm{Pt} / \mathrm{cm}^{2}$ electrodes. This is in agreement with results obtained by Wilson and Gottesfeld ${ }^{2}$. They reported that reasonable performance of thin film electrodes is obtained down to loadings of 0.10 to $0.15 \mathrm{mg} \mathrm{cm}^{-2}$. Increasing prices of $\mathrm{Pt}$ requires further reduction in loading, below that of $0.10 \mathrm{mg} \mathrm{Pt} / \mathrm{cm}^{2}$. This means that the utilization of the catalyst has to be improved. Keeping the Ptloading constant at $0.06 \mathrm{mg} / \mathrm{cm}^{2}$, it is seen (from
Fig.4) that it was possible to improve cell voltage by $150 \mathrm{mV}$ (i.e. from 225 to $375 \mathrm{mV}$ ) by changing the Nafion content of the electrode. Further optimization of electrode composition and preparation procedure is the key to improved Pt-utilization.

\subsection{Commercial electrodes}

Single cells containing commercial Prototech electrodes and Nafion 117 membranes were prepared to constitute a consistent reference for comparison of the performance to that of the thin film electrodes. The performance of cells containing as-received and modified Prototech electrodes are shown in Fig.5.

As-received materials showed poor performance, whereas the impregnation of the electrodes had a tremendous positive effect on cell polarization. These results are in agreement with results reported by Ticianelli et al. ${ }^{20)}$. The large improvement in cell performance followed by impregnation was due to an increased three-phase area, and thus a better Ptcatalyst utilization. It can be seen from Fig. 5 that the electrodes that contained an extra layer of catalyst (applied by vacuum deposition) showed superior performance to the former. In both cases the Nafionsolution penetrates the pores and improves the contact between the electrode and the membrane phase. Comparison of the mass activity (Table 2) show, however, that the extra catalyst layer (corresponding to $0.03 \mathrm{mg} / \mathrm{cm}^{2}$ of $\mathrm{Pt} / \mathrm{Rh}$ ) contributes significantly to the reaction rate. The thin deposited layer facilitates an improved mass activity corresponding to 2500 $\mathrm{mA} / \mathrm{cm}^{2} \mathrm{mg}$. Other investigations ${ }^{6)}$ also showed large mass activity improvements from thin layer sputtered onto the electrode surface. The deposition increases the number of active electrocatalytic sites near the

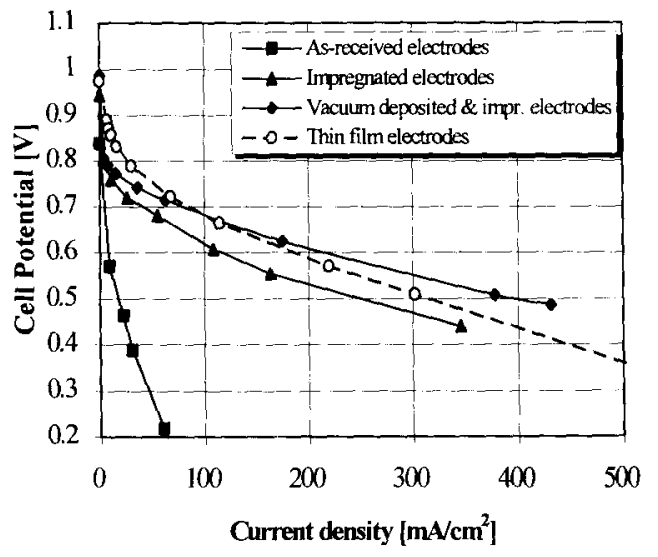

Fig.5 Polarization curves for single fuel cells containing Nafion 117 membrane and different electrodes. $T_{\text {cell }}=70^{\circ} \mathrm{C}, T_{\text {bumidifiers }}=85^{\circ} \mathrm{C}$, $\mathrm{P}_{\mathrm{an}}=\mathrm{P}_{\text {cat }}=4.5$ bar $(450 \mathrm{kPa})$. 
Table 2 Performance comparison of single cells containing different electrodes.

\begin{tabular}{|c|c|c|c|c|}
\hline & Pt-loading & Current* & Mass Activity Pt ${ }^{*}$ & Open Circuit Potential \\
\hline Type of electrode & {$\left[\mathrm{mg} \mathrm{cm} \mathrm{cm}^{-2}\right]$} & {$\left[\mathrm{mA} \mathrm{cm}{ }^{-2}\right]$} & {$\left[\mathrm{mA} \mathrm{cm} \mathbf{c m}^{-2} \mathrm{mg}^{-1}\right]$} & {$[\mathbf{V}]$} \\
\hline As-received & 0.5 & 4.3 & 8.6 & 0.838 \\
\hline Impregnated & 0.5 & 41 & 82 & 0.944 \\
\hline Vacuum deposited \& impr. & 0.53 & 83 & 157 & 0.988 \\
\hline Thin film & 0.1 & 85 & 850 & 0.975 \\
\hline
\end{tabular}

* at $0.7 \mathrm{~V}$

membrane surface. As current density increases, the region where the reaction takes place closes up to the membrane surface. The region is in the range of $4 \mu \mathrm{m}$ at high current densities ${ }^{2)}$.

\subsection{Electrode comparison}

The polarization curve for the single cell containing thin film electrodes is included in Fig.5. This cell is superior to the modified commercial electrodes up to around $100 \mathrm{~mA} / \mathrm{cm}^{2}$. This indicates that the thin electrodes are more reversible and can provide better contact to the membrane. Comparison of the mass activities (Table 2) shows that the thin film electrodes utilize the catalyst two orders of magnitude higher than as-received electrodes at a cell potential of $0.7 \mathrm{~V}$. From the slope of the curves in the linear region (Fig. 5), it seems that the potential losses in the cells with thin film electrodes are higher than those for modified commercial Prototech electrodes. The reasons for the more rapid decline for the thin film electrode may be that i) overpotential is larger due to the very low Pt-loading in thin film electrodes, ii) ohmic loss through the dense thin film electrode is higher compared to the commercial carbon cloth electrode and iii) contact problems may occur between the uncatalyzed carbon cloth backing inserted to support the thin film electrode.

\section{SUMMARY}

The results of this study may be summarised as follows:

1. Thin film electrocatalytic layers were successfully applied directly onto the membrane by spraydeposition.

2. Statistical factorial design of the experiment is a useful tool for studying electrode performance.

3. High polymer content in the thin film electrode and high Pt-loading both gave improved cell performance.

4. The drying temperature of the M\&E assembly should be kept at $125{ }^{\circ} \mathrm{C}$ to reduce membrane degradation.

5. Thin film electrodes exhibited higher Ptutilization than hot pressed commercial electrodes.
6. A detailed description of a SPFC test station operating within adequate temperature and pressure ranges was given.

The Norwegian Research Council (NFR), Nansenfondet and SINTEF are thanked for financial support. Vibeke Andersson is acknowledged for her assistance during electrode preparation and Prof. Signe Kjelstrup Ratkje for her encouragement and valuable discussions. The author is grateful to Johnson Matthey Plc, UK for providing the Pt catalyst material and Cabot, Netherlands for providing carbon black material without catalyst.

\section{REFERENCES}

1) S. Srinivasan, D.J. Manko, H. Koch, A. Enayetullah and J.A. Appleby, J.Power Sources, 29, 367-387 (1990).

2) M.S. Wilson and S. Gottesfeld, J. Appl. Electrochem., 22, 1-7, (1992).

3) J.O. Murphy, G. Duncan Hitchens and D.J. Manko, J.Power Sources, 47, 353-368 (1994).

4) J.O'M. Bockris, S. Srinivasan, Fuel Cells, Their Electrochemistry, McGraw-Hill, USA (1969).

5) T.E. Springer, M.S. Wilson and S. Gottesfeld, J.Electrochem.Soc., 140, No.12,3513-3526 (1993).

6) S. Mukerjee, S. Srinivasan and A.J. Appleby, Electrochim. Acta., 38, No.12, 1661-1669 (1993).

7) P. Millet, T. Alleau, and R. Durand, J. Appl. Electrochem., 23, 322-331 (1993).

8) Z. Poltarzewski, P. Staiti, V. Alderucci, W. Wieczorek and N, Giordano, J. Electrochem. Soc., 139, No.3, 761-764, (1992).

9) E.A. Ticianelli, J.G. Beerey, and S. Srinivasan, J. Appl. Electrochem., 21, 597-605 (1991).

10)E.J.Taylor, E.B. Anderson and N.R.K. Vilambi, J. Electrochem. Soc., 139, No.5, L45L46 (1992). 
11) M.W.Verbrugge, E.W. Schneider, R.S. Conell and R.F. Hill, J. Electrochem. Soc., 139, No.12, 3421-3428 (1992).

12) M.W. Verbrugge and R.F. Hill, J.Electrochem. Soc., 137, No.12, 3770-3777 (1990).

13)A.K. Shukla, P. Stevens, A. Hamnett and J.B. Goodenough, J. Appl. Electrochem., 19, 383386 (1989).

14) H.P Dhar, L.G. Christner and A.K. Kush, $J$. Electrochem. Soc., 134, 3021-3026 (1987).

15)E.A.Ticanelli, C.R. Derouin and S. Srinivasan, J. Electroanal. Chem., 251, 275-295 (1988).

16) T.A. Zawodzinski, Jr., C. Derouin, S. Radzinski, R.J. Sherman, V.T. Smith, T.E. Springer and S.Gottesfeld, J. Electrochem. Soc., 140, No.4, 1041-1047 (1993).
17)T.A. Zawodzinski, Jr., T.E. Springer, J. Davey, R. Jestel, C. Lopez, J. Valerio and S. Gottesfeld, J. Electrochem. Soc., 140, No.7, 1981-1985 (1993).

18)R. Mosdale and P. Stevens, Solid State Ionics, 61, 251-255 (1993).

19)A.M. Kannan, A.K. Shukla and A. Hamnett, $J$. Appl. Electrochem., 18, 149-153 (1988).

20)E.A. Ticanelli, C.R. Derouin, A. Redondo and S. Srinivasan, J. Electrochem. Soc., 135, No.9, 22092214, (1988)

21)Box, W.G Hunter and J.S. Hunter, Statistics for experimenters, An Introduction to Design, Data Analysis, and Model Building, Wiley, USA (1978). 